Uniwersytet Wrocławski

agnieszka.kolodziej@uwr.edu.pl

\title{
NAZEWNICTWO URBOZOONIMICZNE W WYBRANYCH JĘZYKACH ZACHODNIO- I POLUDNIOWOSEOWIAŃSKICH*
}

\author{
Słowa te matyc zne: urbozoonimy, onomastyka, języki słowiańskie
}

Niniejszy artykuł podejmuje zagadnienie nazewnictwa zwierząt domowych, pokojowych w wybranych językach zachodnio- i południowosłowiańskich. Głównym jego celem jest zaprezentowanie nazewnictwa zwierząt w tych językach, wskazanie na czynniki sprawcze determinujące proces nominacji, a także ukazanie podobieństw bądź różnic. Ze względu na ramy objętościowe artykułu omówione zostaną tu jedynie najważniejsze zjawiska oraz tendencje w nazewnictwie urbozoonimicznym wymienionych języków.

Komparatywną analizę materiału przeprowadzono na trzech płaszczyznach: motywacyjnej, formalnej (stanowiących dominujący aspekt tematyczny artykułu) i socjolingwistycznej. Próba materiałowa została pozyskana metodą badań ankietowych i terenowych. W ten sposób zebrano ponad 1500 pojedynczych imion zwierzęcych „obsługujących” różne gatunki zwierząt: psy, koty, świnki morskie, króliki, papugi, chomiki, żółwie, rybki, szczury, fretki, myszy, kanarki, a nawet pająki, jaszczurki czy też myszoskoczki. Jako najbardziej adekwatną do realizowanego tematu wybrano metodę badań synchronicznych z uwzględnieniem aspektu socjolingwistycznego oraz metody semantyczno-inspiracyjnej, zaproponowanej przez J. Strutyńskiego, ze stosownymi modyfikacjami, zarówno w odniesieniu do użytej nomenklatury, jak i podziałów klasyfikacyjnych ${ }^{1}$. Pod względem formalnym w każdej grupie i podgrupie motywacyjnej wyróżniono przeniesienia, czyli formy mianownikowe nazw

\footnotetext{
* Artykuł stanowi rozwinięcie problemów sygnalizowanych w mojej rozprawie doktorskiej poświęconej nazewnictwu zwierząt domowych w wybranych językach słowiańskich.

${ }^{1}$ Cały materiał badawczy został przedstawiony w dwóch schematach: schemat klasyfikacyjny A. Urbozoonimy umotywowane czynnie i schemat klasyfikacyjny B. Urbozoonimy umotywowane biernie. Szczegółowe analizy przeprowadzono w schemacie klasyfikacyjnym A, w którym zastosowano podział trychotomiczny na klasy: 1) urbozoonimy umotywowane pośrednio, 2) urbozoonimy umotywowane bezpośrednio, z wyróżnieniem podklas; urbozoonimy umotywowane wewnętrznie i urbozoonimy umotywowane zewnętrznie, oraz 3) urbozoonimy wielomotywacyjne. W klasach urbozoonimów umotywowanych pośrednio i bezpośrednio wprowadzono dalsze podziały na grupy i podgrupy motywacyjne.
} 
własnych przeniesione bez modyfikacji formalnej, użyte wtórnie na zasadzie metafory bądź metonimii, oraz derywaty słowotwórcze, w których nastapiły zmiany podstawy nazwotwórczej przy użyciu wykładników formalnych.

W zaprezentowanej klasyfikacji każdą podgrupę motywacyjną opatruję jedynie trzema przykładowymi imionami. W przypadku podgrup nieproduktywnych podaje jeden lub dwa przykłady. Urbozoonimy zamieszczone w schemacie klasyfikacyjnym przytaczane są ze wszystkich analizowanych języków i dotyczą różnych gatunków zwierząt. Informacje na temat języka, w którym dane imię zostało poświadczone, oraz gatunku zwierzęcia, które zostało tym zawołaniem obdarzone, podaję za imieniem w nawiasie okragłym. Przy zakwalifikowaniu danej nazwy do przeniesień bądź derywatów słowotwórczych decydująca jest jej podstawa. W zebranym materiale odnotowano przypadki, w których podstawą nazwotwórczą imienia była nazwa w formie derywowanej. Stąd też bierze się występowanie jednostek w pierwotnej wersji w formie zmodyfikowanej słowotwórczo w grupie przeniesień. Przy formach derywowanych słowotwórczo, a także przy formach dwuznacznych podaję nazwę-podstawę.

Zmodyfikowana klasyfikacja urbozoonimów przedstawia się następująco.

I. Urbozoonimy umotywowane czynnie pośrednio

I. 1. Urbozoonimy umotywowane nazwami własnymi.

I. 1. 1. Urbozoonimy umotywowane przez antroponimy.

I.1.1.1. Imiona/nazwiska postaci fikcyjnych znanych z telewizji, filmu, literatury, piosenek:

— przeniesienia: Athos (k, słwc.), Čestimír (k, cz.), Ronie (mk, cz.);

- derywaty: Houmi (od Homer; f, cz.).

I.1.1.2. Imiona/nazwiska znanych postaci historycznych i współczesnych:

— przeniesienia: Bolt (p, słwń.), Peat (ch, cz.), Iggy (p, pol.);

- derywaty: Cleo (od Kleopatra; s, słwń.), Gari (od Garinča; p, sr.), Napi (od Napoleon; k, słwń.).

I.1.1.3. Imiona/nazwiska krewnych i znajomych:

— przeniesienia: Cecilka (od Cecilka; ka, słwc.), Irina (ka, ch.), Terezka (od Terezka; r, cz.);

— derywaty: Juri (od Jurislav; k, ch.), Naja (od Aneja; s, słwń.), Petka (od Petra; s, słwc.).

I.1.1.4. Imiona/nazwiska właściciela zwierzęcia:

— przeniesienia: Eliška (od Eliška; ż, cz.), Iris (ka, słwc.);

- derywaty: Dan (od Dana; p, cz.), Kimi (od Ki[ka] + Mi[chal]; s, słwc.), Nikolina (od Nikola; kr, sr.).

I.1.1.5. Imiona istot bajecznych i mitologicznych:

— przeniesienia: Arwen (s, słwc.), Ciastek (śm, pol.), Fifi (pg, sr.);

— derywaty: Nubis (od Anubis; k, pol.), Smerfuś (od Smerf; k, pol.), Veni (od Venera; s, słwń.). 
I.1.1.6. Urbozoonimy umotywowane przez przezwiska, przydomki, pseudonimy:

— przeniesienia: Agrafka (ka, pol.), Koudy (p, cz.), Toli (ka, słwń.).

I.1.1.7. Urbozoonimy umotywowane przez etnonimy:

— przeniesienia: Aszanti (s, pol.);

- derywaty: Cziro (od Czirokez; p, pol.).

I.1.1.8. Urbozoonimy umotywowane przez nazwy heraldyczne i dynastyczne:

- przeniesienia: Ming (k, pol.).

I.1.2. Urbozoonimy umotywowane przez zoonimy.

I.1.2.1. Imiona zwierząt znane z telewizji, filmu, literatury, piosenek:

— przeniesienia: Donatello (̇̇, cz.), Garfield (k, sr.), Jerry (sz, pol.);

- derywaty: Bobik (od Bob; kr, słwc.), Dex (od Dexter; p, pol.), Mambina (od Mambo; kr, cz.).

I.1.2.2. Typowe imiona zwierzęce:

— przeniesienia: Ferda (św, cz.), Kokolo (pg, ch.) Koki (pg, słwń.);

— derywaty: Azorek (od Azor; p, pol.), Cicmil (od Cica; k, sr.), Micko (od Mica; $\mathrm{k}, \mathrm{sr}$.).

I.1.2.3. Imiona zwierząt należących do krewnych i znajomych:

- przeniesienia: Argo (p, słwc.), Béd’a (pg, cz.), Indy (s, ch.);

— derywaty: Krišsína (od Kristína; ch, cz.), Pyza (od Pysia; ka, pol.), Tobi (od Robi; p, sr.).

I.1.2.4. Imiona związane z nazewniczą tradycją rodzinną:

— przeniesienia: Aziko (k, słwc.), Ňufka (kr, cz.), Toša (k, słwń.);

— derywaty: Chita (od Chikita; kr, cz.), Taja (od Tara; ka, pol.), Laik (od Aik+ pierwsza litera imienia właścicielki; p, słwń.).

I.1.2.5. Imiona o charakterze matro- i patronimicznym:

- przeniesienia: Bony (p, słwc.), Saba (s, pol.), Nella (s, sr.);

— derywaty: Bubik (od Bucka; k, sr.), Dianka (od Diana; ka, pol.), Miškica (od Miško; ka, sr.).

I.1.3. Urbozoonimy umotywowane przez toponimy.

I.1.3.1. Makrotoponimy:

— przeniesienia: Gobi (̇̇, pol.), Potštejn (k, cz.), Rea (s, ch.);

- derywaty: Issa (od Vis; ka, ch.).

I.1.3.2. Mikrotoponimy:

- przeniesienia: nie odnotowano;

- derywaty: Wincenta (od ul. św. Wincentego; ka, pol.).

I.1.3.3. Nazwy lokatywne związane z miejscem pochodzenia lub z miejscem zakupu zwierzęcia:

- przeniesienia: $L e v^{2}$;

\footnotetext{
${ }^{2}$ Respondent wskazał tu motywację związaną z pochodzeniem psa, który jest rosyjskim chartem i dlatego otrzymał rosyjskie imię Lev [Nikolaevič].
} 
— derywaty: Esti (od Estonia; ka, pl.), Kilián (od Chilia; p, cz.), Greco (od Grčija; p, słwń.).

I.1.4. Urbozoonimy umotywowane przez chrematonimy.

I.1.4.1. Instytucjonimy:

- przeniesienia: Duma (p, ch.), Mandragora (s, pol.), Pollos (pg, chr.);

- derywaty: Zigi (od Zig Zag Medveščak; śm, ch.).

I.1.4.2. Nazwy własne rzeczywistości kulturowych (chrononimy, akcjonimy, aktonimy) - nie odnotowano.

I.1.4.3. Unikatonimy (nazwy wyrobów świata techniki oraz ideonimy):

- przeniesienia: Ajša (ka, słwń.), Coma (s, pol.), Tonka (ka, sr.);

- derywaty: Aba (od Abba; ka, sr.), Bandzia (od Wanda i Banda; ka, pl), Pucca Boo (kombinacja imienia kotki i gry peekaboo; ka, ch.).

I.1.4.4. Pragmatonimy (tyronimy, nazwy wyrobów spożywczych, nazwy wyrobów drogeryjnych, nazwy wyrobów cukierniczych i używek, porejonimy, nazwy obuwia, nazwy odzieży etc.).:

— przeniesienia: Ily (s, słwń.), Kofola (s, słwc.), Punto (kr, pol.);

— derywaty: Cotinka (od Cottage; s, cz.), Ferynek (od Ferarri; pg, cz.), Shebby (od Sheba; k, słwc.).

I.2. Urbozoonimy umotywowane nazwami apelatywnymi.

I.2.1. Umotywowane gatunkowymi/rodzajowymi nazwami ze świata fauny.

— przeniesienia: Dog (p, pol.), Hrčak (ch, ch.), Pogona (jk, cz.);

- derywaty: Jazo (od jazavčar; p, ch.), Kocica (od kot; ka, pl), Máčik (od mač$k a ; \mathrm{k}, \mathrm{słwc}$.$) .$

I.2.2. Umotywowane gatunkowymi/rodzajowymi nazwami ze świata flory:

— przeniesienia: Bendžamin (p, sr.), Liczi (ch, pol.), Klementina (kr, ch.);

- derywaty: Grétka (od margarétka; s, słwc.), Lesněnka (od les; ka, cz.), Lili (od lilium; ka, słwń.).

I.2.3. Umotywowane przez nazwy przedmiotów, wytworów:

— przeniesienia: Dárek (k, cz.), Doli (ka, słwń.), Pikollo (ch, pol.);

- derywaty: Gerlíček (od degerli tas; k, cz.).

I.2.4. Umotywowane przez nazwy stanowisk, zawodów, godności, tytułów honorowych i naukowych:

- przeniesienia: Bej (p, pol.), Mona (s, sr.).

I.2.5. Umotywowane przez nazwy pojęć abstrakcyjnych:

- przeniesienia: Indygo (s, pol.).

I.2.6. Umotywowane przez nazwy apelatywne oznaczające relacje pokrewieństwa:

- przeniesienia: Brolis (p, cz.), Seka (s, ch.);

— derywaty: Brachol (od brat; kr, pl.), Mac (od Mc; p, cz.).

I.2.7. Umotywowane przez nazwy apelatywne dotyczące leksyki specjalistycznej: 
— przeniesienia: Čača (s, słwń.), Enter (k, pol.), Tymin (k, cz.);

- derywaty: Alik (od alomorf; p, pol.).

I.3. Umotywowane przez nazwy własne lub apelatywne.

I.3.1. Umotywowane przez nazwy chorób itp.:

- przeniesienia: Down (k, pol.).

I.3.2. Umotywowane przez nazwy zjawisk atmosferycznych itp.:

- przeniesienia: Awalanche (p, słwc.), Tajfun (k, pol.).

I.3.3. Umotywowane przez nazwy pochodzące $\mathrm{z}$ kalendarzy, stron internetowych z kalendarzami (nazwy kalendarzowe):

- przeniesienia: Aza (ka, pol.), Betyna (ka, cz.), Čapi (p, słwń.).

I.3.4. Umotywowane przez nazwy wybrane losowo bądź będące pierwszym pomysłem właściciela (nazwy losowe):

— przeniesienia: Ňufik (od Ňufík; św, cz.), Ignác (k, słwc.), Muri (p, słwń.);

- derywaty: Maxik (od Max; p, cz.).

I.3.5. Umotywowane przez reguły nadawania imion zwierzętom rasowym (nazwy rodowodowe):

- przeniesienia: Arany Meteor Cicero (p, ch.), Daylight (ka, słwń.), Dodi (p, pol.);

— derywaty: Aronko (od Aron; p, słwc.), Betka (od Betty Broadway Girl Bettty Boop; s, słwń.), Čičolka (od Čiča; ka, słwc.).

II. Urbozoonimy umotywowane bezpośrednio

II.1. Urbozoonimy umotywowane wewnętrznie.

II.1.1. Urbozoonimy umotywowane przez cechę zewnętrzną.

II.1.1.1. Umotywowane przez nazwy symilatywne - wygląd ogólny.

II.1.1.1.1. Wielkość, tusza, sposób poruszania, umiejętności:

- przeniesienia: Baryła (k, pol.), Drobižek (od drobižek; p, słwń.), Mala (s, sr.);

- derywaty: Kepico (od kepa; ch, słwń.), Puszek (od puszysty; k, pol.), Ťapko (od t'apkat; p, słwc.).

II.1.1.1.2. Barwa okrycia ciała lub części ciała:

— przeniesienia: Flekica (od flekica; ka, sr.), Kropka (od kropka; s, pol.), Pika (ka, słwń.);

— derywaty: Ciapek (od ciapowaty; p, pol.), Pegica (od pega; s, sr.), Strakoš (od strakatý; p, słwc.).

II.1.1.1.3. Zewnętrzne podobieństwo do zwierzęcia innego lub własnego gatunku:

- przeniesienia: Cica (ka, słwc.), Gizmo (p, ch.), Szyszunia (szn, pol.);

- derywaty: Bulgot (od buldog; p, pol.), Lavić (od lav; p, ch.), Tiguška (od tigrik; ka, słwc.). 


\section{II.1.1.2. Charakterystyczna część ciała:}

- przeniesienia: Eye (p, ch.), Radar (p, słwc.), Šapica (s, sr.);

— derywaty: Bubáček (od bubák; k, cz.), Tačka (od tačko; ka, słwń.), Wypłosz (od wypłoszone oczy; k, pol.).

II.1.2. Urbozoonimy umotywowane przez cechę wewnętrzną.

II.1.2.1. Umotywowane przez własności psychiczne:

- przeniesienia: Adolf (p, pol.), Arya (s, ch.), Sokrat (p, słwń.);

- derywaty: Craizol (od crazy; p, pol.), Glupača (od glupa; ka, ch.), Rambica (od Rambo; ka, ch.).

II.1.2.2. Umotywowane przez własności fizyczne:

— przeniesienia: Hipper (k, słwń.), Monkey (k, cz.), Rumi (p, pol.);

— derywaty: Gryś (od gryźć; p, pol.), Mazlik (mazlit se; kr, cz.), Mňouka (od mňoukat; ka, cz.).

II.1.2.3. Nazwy temporalne, określające wiek zwierzęcia lub okres rozrodu:

— przeniesienia: Deda (k, sr.), Djaru (p. cz.), Senior (k, pol.);

- derywaty: Juniora (od junior; ka, pol.).

II.1.3. Urbozoonimy dźwiękonaśladowcze:

— przeniesienia: Chrupek (k, pol.), Čiči (k, słwc.), Harley (k, ch.);

- derywaty: C(v)ilika (od cvilit; ka, ch.), Skrzetuski (od skrzeczeć; k, pol.).

II.1. Urbozoonimy umotywowane zewnętrznie.

II.2.1. Nazwy pamiątkowe i urodzinowe:

— przeniesienia: Albert (k, cz.), Alžbeta (s, słwc.), Gym (p, ch.);

- derywaty: Božića (od božić, św, ch.), Mika (od mačka izpod kolesa avtomobila; ka, słwń.), Slamsiak (od slumsy; p, pol.).

II.2.2. Nazwy życzeniowe:

- przeniesienia: Hiro (p, pol.), Nijah (s, słwc.), Tyranie (wąż, cz.);

— derywaty: Hali (od Halona; s, ch.), Mađi (od magični; k, sr.), Srećko (od srećan; p. sr.).

II.2.3. Nazwy pragmatyczne (nazwy w swej formie i treści łatwe do zapamiętania, miłe w brzmieniu, często krótkie):

- przeniesienia: Čiko (k, cz.), Piko (pg, ch.), Szarik (szn, pol.);

— derywaty: Berni (od Bernadett; s, słwc.), Jorka (od Rojka; s, pol.), Kubko (od Kubo; k, słwc.).

II.2.4. Nazwy oryginalne (motywowane przez wyrazy oryginalne, niepowtarzalne):

— przeniesienia: Century Fox (p, cz.), Gridi (k, pol.), Šumienka (ka, słwc.);

- derywaty: Ferdek (od Ferdynand; k, pol.), Lili (od Lilien; ka, cz.).

II.2.5. Nazwy hobbystyczne (motywowane przez wyrazy związane z zainteresowaniami, upodobaniami właściciela zwierzęcia):

- przeniesienia: Frojd (k, sr.), Grafik (k, pol.), Sita (s, ch.);

- derywaty: Danuško (od Daniel; pg, sk.), Květka (od Květoslava; ka, sk.), Tinka (od Timi; ka, słwń.). 
II.2.6. Nazwy ludyczne (motywowane przez wyrazy wyrażające przekorę, zabawę, grę słowną):

— przeniesienia: Frodo (k, cz.), Parter (p, pol.), Stanislav (pj, sr.);

— derywaty: Bela (od biela; s, słwc.), Maza (maziti se; s, sr.). nym):

II.2.7. Nazwy posesywne (motywowane przez wyrazy o charakterze posesyw-

— derywaty: Mija (od mój; ka, pol.), Tutty (od tutto; p. słwń.).

II.2.8. Nazwy socjologiczne (motywowane przez wyrazy określające stany społeczne, przynależność do grup społecznych):

- przeniesienia: Hipis (p, pol.).

III. Urbozoonimy wielomotywacyjne

- przeniesienia: Ariumi (ka, cz.), Behemot (k, pol.), Biggie (p, słwc.);

- derywaty: Draguljub (od drag i ljubiti se; k, sr.), Kobližek (od kobliha; p, cz.), Šnúrik (od šnúrka; k, słwc.).

Najliczniejszą klasę w zebranym materiale tworzą urbozoonimy umotywowane pośrednio, na drugim miejscu plasują się urbozoonimy umotywowane bezpośrednio, najmniej liczna jest natomiast klasa urbozoonimów wielomotywacyjnych. W obrębie poszczególnych grup motywacyjnych materiał rozkłada się nieco inaczej. Najliczniej zaświadczona została podgrupa urbozoonimów umotywowanych przez barwę pokrycia ciała lub części ciała (II.1.1.1.2 — 8,23\%), np.: pol. Amber (kotka): „Kot jest koloru bursztynu, więc został ochrzczony Amber (bursztyn z jęz. ang.)”. Drugie miejsce zajmują urbozoonimy umotywowane przez nazwy pragmatyczne (II.2.3 - 7,52\%), np.: cz. Easy (kot): „Líbí se mi. Jednoduchá, max. dvojslabičná jména přri zavolání zřetelná”. Licznie zaświadczone zostały motywacje w postaci: imion zwierząt znanych z telewizji, filmu, literatury, piosenek (I.1.2.1 - 6,74\%), np. sr. Badi (pies): ,pas iz filma Badi pas košarkaš”, wielkości, tuszy, sposobu poruszania się (II.1.1.1.1 - 5,82\%), np. słwc. Twiggy (kotka): ,Twiggy bola vel'mi chudá ako ta modelka", imion związanych z nazewniczą tradycją rodzinną (I.1.2.4 4,68\%), np. słwń. Riki (pies): „ime prejšnjega kužka”, imion rodowodowych (I.3.5 - 4,18\%), np. ch. Antal (pies): „Psu je ime u rodovniku”, własności psychicznych (II.1.2.1 - 3,90\%), np. pol. Pirania (suka): „kocham ją bardzo, ale czasami jest zła, wredna jak pirania", imion/nazwisk postaci fikcyjnych znanych z telewizji, filmu, literatury, piosenek (I.1.1.1. — 3,83\%), np. słwń. Arya (kotka): „Arya po deklici iz serije Game of Throne", nazw pamiątkowych i urodzinowych (II.2.1 3,33\%), np. cz. Albert (kot): „Albert má svátek v den, kdy jsme ho zachránili”, imion postaci bajecznych i mitologicznych (I.1.1.5 - 3,12\%), np. Behemot (kot): „kot Behemot z Mistrza i Małgorzaty” etc. Poniżej zamieszczam tabelę prezentującą najbardziej produktywne podgrupy motywacyjne. 


\begin{tabular}{|c|c|}
\hline Produktywność wybranych podgrup motywacyjnych & {$[\%]$} \\
\hline Barwa pokrycia ciała lub części ciała (II.1.1.1.2.) & 8,23 \\
\hline Nazwy pragmatyczne (II.2.3.) & 7,52 \\
\hline Imiona zwierząt znane z telewizji, filmu, literatury, piosenek (I.1.2.1.) & 6,74 \\
\hline Wielkość, tusza, sposób poruszania, umiejętności (II.1.1.1.1.) & 5,82 \\
\hline Imiona związane z nazewniczą tradycją rodzinną (I.1.2.4.) & 4,68 \\
\hline Nazwy rodowodowe (I.3.5.) & 4,18 \\
\hline Imiona motywowane przez własności psychiczne (II.1.2.1.) & 3,90 \\
\hline $\begin{array}{l}\text { Imiona/nazwiska postaci fikcyjnych znanych z telewizji, filmu, literatury, } \\
\text { piosenek (I.1.1.1. ) }\end{array}$ & 3,83 \\
\hline Nazwy pamiątkowe i urodzinowe (II.2.1.) & 3,33 \\
\hline Imiona istot bajecznych i mitologicznych (I.1.1.5.) & 3,12 \\
\hline Imiona motywowane przez własności fizyczne (II.1.2.2.) & 2,91 \\
\hline Nazwy oryginalne (II.2.4.) & 2,77 \\
\hline Imiona motywowane gatunkowymi/rodzajowymi nazwami ze świata fauny (I.2.1.) & 2,34 \\
\hline Imiona/nazwiska znanych postaci historycznych i współczesnych (I.1.1.2.) & 2,27 \\
\hline Typowe imiona zwierzęce (I.1.2.2.) & 2,06 \\
\hline Imiona zwierząt należących do krewnych i znajomych (I.1.2.3.) & 2,06 \\
\hline Charakterystyczna część ciała (II.1.1.2.) & 1,91 \\
\hline Nazwy kalendarzowe (I.3.3.) & 1,84 \\
\hline Unikatonimy (I.1.4.3.) & 1,77 \\
\hline Pragmatonimy (I.1.4.4.) & 1,70 \\
\hline Zewnętrzne podobieństwo do zwierzęcia innego lub własnego gatunku (II.1.1.1.3.) & 1,56 \\
\hline Nazwy hobbystyczne (II.2.5.) & 1,49 \\
\hline Nazwy ludyczne (II.2.6.) & 1,35 \\
\hline Nazwy losowe (I.3.4.) & 1,13 \\
\hline Urbozoonimy dźwiękonaśladowcze (II.1.3.) & 1,06 \\
\hline Imiona o charakterze matro- i patronimicznym (I.1.2.5.) & 0,71 \\
\hline
\end{tabular}


W produktywności motywacji wśród poszczególnych gatunków zwierząt widoczne są inne proporcje ${ }^{3}$. W nazewnictwie psów najczęściej wykorzystywane są źródła motywacyjne w postaci nazw pragmatycznych, krótkich, miłych w brzmieniu, łatwych do zapamiętania (II.2.3 - 9,12\%). Drugie miejsce przypada imionom rodowodowym (I.3.5 - 7,84\%). Dopiero na trzecim miejscu znajdują się nazwy powstałe od innych zoonimów, imiona zwierząt znanych z filmu, literatury, telewizji, piosenek (I.1.2.1 - 7,13\%). Do produktywnych w zebranym materiale należy zaliczyć również imiona motywowane przez barwę pokrycia ciała (II.1.1.1.2 — 5,79\%), imiona/nazwiska postaci fikcyjnych znanych z telewizji, filmu, literatury, piosenek (I.1.1.1 - 5,54\%), imiona umotywowane przez wielkość, tuszę, sposób poruszania się (II.1.1.1.1 - 5,22\%) czy też nazwy związane z nazewniczą tradycją rodzinną (I.1.2.4 - 5,18\%), powstałe od imion/nazwisk znanych postaci historycznych i współczesnych (I.1.1.2 — 4,45\%) i umotywowane przez własności psychiczne (II.1.2.1 - 3,76\%).

W przypadku imion kotów najwyższą rangę uzyskały te, dla których źródłem motywacyjnym były zewnętrzne własności zwierzęcia: barwa pokrycia ciała lub jego części (II.1.1.1.2 - 12,87\%), wielkość, tusza, sposób poruszania się (II.1.1.1.1 — $6,49 \%$ ), następnie imiona zwierząt znane z filmu, literatury, piosenek (I.1.2.1 $6,41 \%$ ) etc.

Zoonimy znane z filmu, literatury, piosenek (I.1.2.1 - 12,76\%), obok imion motywowanych przez wielkość, tuszę, sposób poruszania się (II.1.1.1.1 - 10,01\%) i własności fizyczne (II.1.2.2 — 9,57\%), stanowiły główne źródło motywacji imion słowiańskich królików.

Własności fizyczne i barwa okrycia ciała lub części ciała (II.1.2.2; II.1.1.1.2 — $11,08 \%$ ) to motywacje wykorzystywane przez respondentów w nazewnictwie świnek morskich.

Wśród papug z kolei najpopularniejsze były nazwy pragmatyczne (II.2.3 14,69\%) i umotywowane przez własności fizyczne (II.1.2.2 - 11,54\%).

Motywacja związana z barwą pokrycia ciała (II.1.2.2) jest również najproduktywniejszym źródłem imion chomików (22,64\%) i szczurów (13,55\%).

Zależności między płcią zwierzęcia a nadanym mu imieniem w większości przypadków zostały zachowane. Nielicznie odnotowano imiona żeńskie nadane osobnikom płci męskiej czy też męskie nadane samicom, np. Jadranka (kot), Leni (pies), Toyota (pies), Messi (kotka). Wybieranym przez respondentów imieniem, które „obsługiwało" obydwie płcie, było imię Charlie.

Analiza materiału onimicznego wykazała, iż bardzo rzadkie są źródła motywacji w postaci: toponimów, np. pl. Gobi (źółw): ,inspiracją dla imienia była pustynia Gobi", etnonimów, nazw dynastycznych, heraldycznych, nazw stanowisk, zawodów, nazw przedmiotów, nazw chorób, schorzeń, nazw oznaczających

\footnotetext{
${ }^{3}$ Ze względu na ramy objętościowe artykułu nie zamieszczam dodatkowych tabel prezentujących szczegółowe wyniki analizy.
} 
relacje pokrewieństwa, np. cz. Brolis (pies): „Pojmenoval ho tak původní majitel, který žije v ČR, ale pochází z Litvy. Původně byli 2 pejsci, sourozenci - fenka a pes, a pojmenoval je litevsky sestra a bratr, a bratr = Brolis"; nazw abstrakcyjnych; nazw zjawisk atmosferycznych; nazw z zakresu leksyki specjalistycznej, np. pol. Epi (szczur): „skrót związku chemicznego Epichloryhydryna = Epi)”; nazw posesywnych, np. słwń. Tutty (pies): „Izpeljano iz italijanskega izraza tutto - vse, ker mi psička pomeni vse" czy też nazw o charakterze socjologicznym, wskazujących na przynależność do grup społecznych lub subkultur.

Przechodząc do uwag dotyczących płaszczyzny formalnej, podkreślić należy, że najproduktywniejszym sposobem derywacji słowotwórczej w całym materiale okazała się derywacja afiksalna $(63,78 \%)^{4}$, na drugim miejscu uplasowała się derywacja paradygmatyczna (26,98\%). Rzadkością okazały się derywaty dezintegralne $(4,84 \%)$, alternacyjne $(3,08 \%)$, kompozycyjne $(1,17 \%)$ czy reduplikacje $(0,15 \%)$. Proporcje te jednak w analizach prowadzonych dla poszczególnych języków są trochę odmienne - w językach chorwackim i słoweńskim dominowała derywacja paradygmatyczna, a nie - jak w pozostałych — afiksalna. Występowanie w materiale onomastycznym zdecydowanie większej liczby struktur prostych niż derywowanych podkreśla słuszność uwagi S. Warchoła, stanowiącej o różnicy między tradycyjnymi zoonimami (jak wynika z przeprowadzonych badań również nad współczesnymi nazwami zwierząt) a antroponimami. Tym pierwszym badacz przypisuje przeważająca obecność form prostych oraz ograniczoną i wyspecjalizowaną grupe formantów słowotwórczych (Warchoł 2003: 75, por. też Mrózek 1996). W przypadku derywacji afiksalnej respondent ma do wyboru o wiele bogatsze zaplecze morfemów słowotwórczych niż końcówek fleksyjnych towarzyszących derywatom paradygmatycznym, mogąc tworzyć struktury derywowane: jednostopniowe (np. za pomocą formantów: -ek, -ák, -as etc.), dwustopniowe (np.: -inka, -ulka, -ísek etc.) i trzystopniowe (np.: -ulinka, -ulíšek) (zob. np. Mrózek 1994: 186). W przeanalizowanym materiale są to w większości formanty hipokorystyczne, deminutywne, rzadko augmentatywne.

Chociaż kreator zwierzęcego imienia ma do wyboru bogate zaplecze wykładników formalnych, to jednak potwierdza się ograniczona liczba formantów, które można uznać za „wyspecjalizowane” i charakterystyczne, w tym wypadku zarówno dla urbozoonimii, jak i rurozoonimii. Formanty z podstawowymi elementami -l, -ch (zob. Warchoł 2003; Warchoł, Strutyński 2004), uznawane za produktywne w zoonimii ludowej, w imionach zwierząt pokojowych pojawiają się sporadycznie, a charakterystyczne są one przede wszystkim dla języków zachodniosłowiańskich ${ }^{5}$. Istotne jest to, że w przypadku urbozoonimicznych formacji derywowanych zdarzają się formanty wielostopniowe powstałe z formacji hipokorystycznych, choć bardzo

${ }^{4}$ Zamieszczam tu jedynie wyniki procentowe poświadczeń.

${ }^{5}$ B. Lindert $(1970,1980)$ zwraca uwagę na obecność tego typów formantów w nazwach pospolitych zwierząt serbskich i chorwackich. 
rzadko, podobnie jak w antroponimach śląskich, które zdaniem S. Warchoła (2003: 71) nie są odnotowane w tradycyjnych strukturach zoonimicznych ${ }^{6}$.

Wśród formacji paradygmatycznych najliczniej zaświadczone są derywaty reprezentujące przymiotnikowy paradygmat fleksyjny w funkcji formantu, który — co należy podkreślić — charakterystyczny jest przede wszystkim dla zdrobnień obcojęzycznych ${ }^{7}$. Drugie miejsce zajmują struktury w postaci rzeczownikowego paradygmatu męskiego w funkcji formantu. Rzeczownikowy paradygmat żeński w funkcji formantu należy do najmniej licznych. Odnośnie do derywatów kompozycyjnych, będących wśród urbozoonimów rzadkością, wspomnieć można, że trzykrotnie wykorzystany został starosłowiański przyrostek -sław (-slav), charakterystyczny w zebranym materiale dla języków zachodniosłowiańskich i odnotowywany także przez J. Strutyńskiego (1996a), a raz zaświadczono formant -ljub. Oprócz wspomnianych sufiksów dwukrotnie odnotowano także przedrostek mini- o charakterze prefiksoidu, wskazujący na wielkość obiektu nominowanego.

Przechodząc do omówienia czynników motywacyjnych, przyznać należy, że w przypadku nazw własnych zwierząt domowych respondenci mają wprost nieograniczone możliwości nazwotwórcze, uzależnione przeważnie od pobudek osobistych, a także wyobraźni kreatora imienia. Zaplecze motywacyjne nazw własnych zwierząt jest — jak wynika z przeprowadzonej analizy — bardzo obszerne i zróżnicowane. Dzieje się tak przede wszystkim dlatego, że urbozoonimy reprezentują kategorię bionimów niekodyfikowanych, nazw niestabilnych, ulotnych. Czynniki wpływające na postać obieranego przez kreatora imienia mogą bezpośrednio odnosić się do obiektu nominowanego, wskazując na jego cechy charakterystyczne oraz określając własności wewnętrzne. Mogą to być także czynniki zewnętrzne, związane $\mathrm{z}$ wydarzeniem pośrednio nawiązującym do referenta, ponadto szeroko pojęte media, reklama, polityka czy też czynniki socjologiczne.

Pod wpływem mediów zwierzęta otrzymują imiona z antroponimicznym i zoonimicznym źródłem inspiracji imionami/nazwiskami postaci fikcyjnych (I.1.1.1.), bajkowych i mitologicznych (I.1.1.5.) oraz zoonimów znanych z telewizji, filmów, książek (I.1.2.1.), które pojawiają się także w grupach nazw motywowanych pośrednio i bezpośrednio.

Jako reprezentatywne można wymienić takie tytuły, jak: Gwiezdne wrota (Vala (szczur), Selmak (szczur)), Władca Pierścieni (Arwen (suka), Frodo (pies)), Hary Potter (Harry (pies), Dobby (pies)), Simpsonowie (Meggi (psy, koty), Sněhulka (kotka), Houmí (fretka)), Gra o tron (Arya, Kal Drogo), Smerfy (Smerfuś (kot), Gricko (kot), Smorko (kot)), Drakula (Mina (psy)) Dexter's Laboratory (DeeDee (świn-

${ }^{6}$ Badacz wskazuje także jako różnicę między tradycyjnymi strukturami zoonimicznymi a antroponimami brak derywatów odimiennych i odmiejscowych, np. z formantami -ski, -owski etc., charakterystycznych dla antroponimii (zob. Warchoł 2003: 71).

7 Na występowanie samogłoski $i(y)$ w nazwach zwierząt rasowych zwraca także uwagę J. Bubak (1986: 189), podkreślając, iż duża część tego typu nazw należy do tworów sztucznych. 
ka morska, pies)), Alf (Alf (psy)), Król Lew (Simba (2 koty), Chiara (suka)), film o kocie Garfieldzie (koty), film o psie Scooby Doo (dwa psy), Rex (2 psy) z serialu Komisarz Rex, kreskówkę Tom i Jerry, książkę/film Trzej muszkieterowie, bajkę o kocie Murim, piosenkę Ajša (dwa koty, pies), kreskówkę Hello Kitty, kreskówkę o śwince Pepie film Marley \& Me etc.

W zebranym materiale pojawiają się również imiona/nazwiska postaci historycznych i współczesnych oraz postaci mitologicznych, które występują we wszystkich językach z różną frekwencja, zarówno w klasie nazw własnych, jak i tych umotywowanych zewnętrznymi oraz wewnętrznymi własnościami. Co istotne, tylko w stosunku do niektórych możemy mówić o produktywności — przede wszystkim w odniesieniu do imion zaczerpniętych z mitologii, np. Argo, Hektor, Zeus. Imiona takie, jak: Ajas, Afrodyta, Ares, Freya, Isis, Kali, Nubis, Odin, Veni etc., odnotowano sporadycznie ${ }^{8}$. Innym źródłem inspiracji jest polityka. Już w latach pięćdziesiątych XX w. H. Górnowicz zwrócił uwagę na ten typ motywacji, wyróżniając w swym schemacie klasyfikacyjnym imiona znienawidzonych władców (zob. Górnowicz 1959). Występowanie nazw motywowanych imionami/nazwiskami osób ze świata polityki dostrzega m.in. J. Strutyński (1996a; por. również Decyk 1996). W zebranym materiale nazwy te pojawiają się sporadycznie, por. np. polską nazwę Adolf (pies) — ,jest władczy zupełnie jak Hitler”, czeską Fidel (kameleon) — „Má červené hrdlo a kouše”, słoweńską Jadranka (kot) — „uvožen iz Hrvaške, ker smo mislili, da je punca, smo ga poimenovali po hrvaški predsednici Jadranki Kosor". Tego typu imiona mogą wyrażać nie tylko negatywny stosunek do polityków, ale także stosunek neutralny bądź pozytywny9.

Wśród źródeł motywacyjnych, oddziałujących pośrednio lub bezpośrednio, wymienić należy reklamę. Zjawisko to ilustrują następujące przykłady: sr. Janko (kot) — „reklama za tele2”, słwń. Rosita (kotka) — „Rosita pa je dobila ime po televizijskem oglasu za moje najljubše piškote v kateri nastopa kokoška Rosita". Przy innych źródłach motywacji, np. chrematonimów (np. Cotinka, Mercinka, Toyota), nazw umotywowanych zewnętrzną cechą zwierzęcia (np. Monty, Snickers), reklama stanowi czynnik pośredni.

W przypadku motywacji bezpośrednich, przy których dość często podstawa zoonimiczna jest formalnie równa kreowanej nazwie (bądź formalnie zmodyfikowana), ważnym czynnikiem motywującym jest wygląd zewnętrzny zwierzęcia - przede wszystkim barwa pookrycia ciała lub jego części. Najliczniejsze motywacje zostają utworzone od koloru białego (np. Belko, Snežka, Ice, Bili), dalej - czarnego (Černoušek, Uhlik, Blekyna, Nero, Shavi, Garo), siwego (Iva,

8 J. Strutyński zwraca uwagę, że imiona postaci bajecznych i mitologicznych, kojarzące się z czarną magią, śmiercią, złem, nadawane są przede wszystkim kotom, a te kojarzące się pozytywnie — psom.

9 Świadczą o tym badania przeprowadzone przeze mnie w 2008 r., na których podstawie został przygotowany referat Polityka jako źródło motywacji w procesie nominacji jednostek urbozoonimicznych, wygłoszony podczas konferencji „Talenty 2009”. 
Sivko, Sivka, Szaron, Sivi), rzadziej — różowego, żółtego, brązowego, rudego czy tė̇ niebieskiego (np. Amber, Strakoš, Bouře, Ruža, Pink, Rudi, Rýza, Žuća, Žutka). Motywacja kolorem sierści, ubarwieniem należy do najproduktywniejszych zarówno dla urbozoonimów, jak i rurozoonimów (zob. np.: Abramowicz 1996; Decyk 1996; Odaloš 1996; Warchoł, Strutyński 2004; Brozović Rončević, Čilaš Šimpraga 2008 etc.).

Przeprowadzone analizy wykazały, że coraz mniej jest imion tradycyjnych, rodzimych. Oczywiście tego typu imiona są poświadczone w każdym z analizowanych pod tym kątem języków słowiańskich, odnotowano ich jednak mniej niż nazw zagranicznych, utworzonych w przeważającej większości na bazie antroponimów. Tradycyjne urbozoonimy możemy spotkać wśród imion motywowanych przede wszystkim wielkością, tuszą, sposobem poruszania się zwierzęcia (II.1.1.1.1), np.: Paczuś, Špekáček, Ťapko, Mrvica, Drobižek, oraz barwą pokrycia ciała (II.1.1.1.2), np.: Kropka, Fliček, Uhlik, Snežka, w typowych imionach zwierzęcych (I.1.2.2), np.: Reksio, Azor, Murko, Kokolo, Pika, czasami w podgrupach inspirowanych przez imiona krewnych i znajomych (I.1.1.3), np.: Tereza, Manji, Dragiša, Janez, czy też przez imiona właściciela zwierzęcia (I.1.1.4), np.: Żancia, Eliška.

Modne stają się nazwy oryginalne, takie, które są krótkie i miłe w brzmieniu, często jedno- lub dwusylabowe (por. np. Bubak 1996; Jakus-Borkowa 1996; Matejčík 1996; Nowakowska 2001 etc.), w większości będące strukturami sztucznymi, pełniącymi jedynie funkcję pragmatyczną.

E. Jakus-Borkowa (1996) w artykule na temat zoonimii ogrodów zoologicznych stwierdziła, że funkcjonują w zasadzie trzy sposoby współczesnej nominacji zwierząt: o charakterze przezwiskowym na bazie leksyki apelatywnej, na podobieństwo antroponimów oraz twory sztuczne. Model zaproponowany przez badaczkę jak najbardziej odzwierciedla nie tylko zoonimię ogrodów zoologicznych, ale również urbozoonimię czy też rurozoonimię.

Zaobserwować również można przewagę liczebną form obcojęzycznych nad imionami tradycyjnymi, rodzimymi. B. Walczak słusznie zauważa:

Na gruncie zoonimii wpływy obce ujawniły się już w materiale siedemnastowiecznych nazw psów myśliwskich (podczas gdy - choć późniejsze - nazewnictwo krów, wołów i byków było w zasadzie od nich wolne), jednak prawdziwy zalew nazw obcych widoczny jest dopiero dzisiaj w zoonimii miejskiej (2004: 40).

W materiale onimicznym struktury ze źródłem motywacji w postaci nazwy własnej, najczęściej z podstawą antroponimiczną, przeważają nad nazwami z apelatywną bazą zoonimiczną (por. Strutyński 1996a). Antroponimy bowiem pojawiają się również w grupie nazw umotywowanych bezpośrednio, w podgrupach inspirowanych zewnętrzną bądź wewnętrzną własnością zwierzęcia oraz w grupie nazw umotywowanych czynnikami zewnętrznymi. 
$\mathrm{W}$ toku analizy stwierdzono, że mamy do czynienia z bardzo małą powtarzalnością imion oraz że sama motywacja, wbrew pozorom, nie jest zależna od wykształcenia respondenta. Wśród najczęściej nadawanych przez słowiańskich respondentów nazw wymienić należy imiona: Lili, zaświadczone aż dwunastokrotnie dla trzech gatunków, Max, użyte w odniesieniu do 10 osobników dwóch gatunków, Luna, odnotowane osiem razy dla trzech gatunków, Bony, Charlie (zapis w trzech wariantach), Mrvica, użyte siedem razy dla dwóch, trzech gatunków; dla dwóch gatunków sześciokrotnie zostały użyte imiona, takie jak: Bella (zapis w dwóch wariantach), Megi (zapis w czterech wariantach), Mini (zapis w trzech wariantach), Chilly (zapis w czterech wariantach) etc. Do imion charakterystycznych dla psów zaliczyć można takie, jak: Ajax, Don, Kora, Lucky, Maza, Saba, Zeus, Zoja, dla kotów - Beba, Bruno, Gerfield, Kitty, Mica, Murko etc., a dla królików - $\check{N} u f k a$. Co istotne, wiele imion ma kilka wariantów zapisu. Wiek i płeć respondentów/autorów imion również diametralnie nie wpływają na wybór motywacji.

Porównując nazewnictwo zwierząt w wybranych językach zachodnio- i południowosłowiańskich, urbozoonimy umotywowane pośrednio (I) najliczniej zostały zaświadczone we wszystkich językach zachodniosłowiańskich i jednym południowosłowiańskim — słoweńskim. W językach serbskim i chorwackim najpopularniejsza była klasa nazw umotywowanych bezpośrednio (II). Urbozoonimy wielomotywacyjne (III) najliczniej występują w językach czeskim, słowackim, słoweńskim i chorwackim, najrzadziej — w polskim i serbskim.

Jeśli chodzi o produktywność w obrębie poszczególnych grup semantycznych, to wyniki procentowe, dotyczące produktywności motywacji o charakterze antroponimicznym bądź zoonimicznym oraz motywacji w postaci własności wewnętrznych lub zewnętrznych, przedstawiają się podobnie, chociaż należy zwrócić uwagę, iż wynik procentowy niekoniecznie plasuje dane źródło motywacyjne na tej samej pozycji co w innym języku.

We wszystkich językach poddanych analizie najproduktywniejszymi źródłami są nazwy umotywowane przez barwę pokrycia ciała lub części ciała (II.1.1.1.2), nazwy motywowane wielkością, tuszą, sposobem poruszania się (II.1.1.1.1), zoonimami znanymi z telewizji, filmów, książek (I.1.2.1), imionami postaci fikcyjnych znanych z telewizji, filmu, literatury (I.1.1.1). Pozostałe źródła motywacyjne są zróżnicowane w poszczególnych językach — w jednych bardziej produktywne, w drugich rzadkie. Dotyczy to źródła motywacji w postaci nazw pragmatycznych (II.2.3), które należy do bardzo popularnych w językach południowosłowiańskich oraz w języku słowackim, mniej popularne jest natomiast w języku czeskim i rzadko występuje w języku polskim. Podobną sytuację obserwujemy na przykładzie imion rodowodowych (I.3.5), należących do produktywnych w językach: słoweńskim, słowackim, serbskim, rzadziej natomiast zaświadczonych w języku chorwackim, czeskim i polskim. Imiona inspirowane nazwami związanymi z tradycją 
rodzinną (I.1.2.4) należy uznać za produktywne dla języków: czeskiego, serbskiego, polskiego, słoweńskiego i słowackiego. Motywacja pamiątkowa i urodzinowa (II.2.1) jest charakterystyczna głównie dla języków czeskiego i chorwackiego, nazwy pochodzące od nazwisk/imion postaci historycznych i współczesnych — dla chorwackiego, słoweńskiego i słowackiego. Imiona istot bajkowych i mitologicznych (I.1.1.5) w zooonomastykonie najliczniej zaświadczono w języku polskim, a nazwy powstałe od imion/nazwisk krewnych i znajomych (I.1.1.3) oraz imion pochodzących z kalendarzy (I.3.3) — w języku słowackim. Imion inspirowanych nazwami temporalnymi (II.1.2.3) nie odnotowano w języku słowackim, inspirowanych imionami/nazwiskami właściciela zwierzęcia (I.1.1.4) nie poświadczono w języku chorwackim, umotywowanych zewnętrznym podobieństwem do zwierzęcia (II.1.1.1.3) — w języku słoweńskim, w języku czeskim brak natomiast imion o charakterze matro- i patronimicznym (I.1.2.5).

Dla standardów zachodniosłowiańskich najproduktywniejsza okazała się derywacja afiksalna. Wśród języków południowosłowiańskich afiksacja jako najpopularniejszy zabieg słowotwórczy została z kolei odnotowana jedynie w języku serbskim, w językach chorwackim i słoweńskim najwyższą pozycję zajmuje natomiast derywacja paradygmatyczna.

W zebranym materiale nazewniczym w przeważającej większości mamy do czynienia ze strukturami hipokorystycznymi, rzadziej natomiast zamiarem kreatora nazwy jest wskazanie na wielkość obiektu nominowanego. Ponadto warto zauważyć, że niektóre formanty, przede wszystkim z podstawowym elementem $-k$, obsługują zarówno formacje hipokorystyczne, jak i deminutywne.

Konkludując: nazewnictwo urbozoonimiczne charakteryzuje duża różnorodność. Ze względu na status prawny jednostek urbozoonimicznych jako nazw niekodyfikowanych, ulotnych kreatorzy imion zwierząt pokojowych mają wprost nieograniczone możliwości nazwotwórcze przede wszystkim pod względem doboru podstaw motywacyjnych oraz wykładników formalnych. Przeprowadzone badania wykazały, iż coraz mniej jest imion tradycyjnych, rodzimych, które pojawiają się najczęściej w nazwach umotywowanych wielkością, tuszą, sposobem poruszania się zwierzęcia. Widoczna jest tendencja do nadawania imion modnych, miłych w brzmieniu, krótkich, które w większości są strukturami sztucznymi, pełniącymi funkcję pragmatyczną. W toku badań stwierdzono, że o wiele więcej jest imion w formie przeniesień bez zmiany podstawy nazwotwórczej niż derywowanych.

Istotna jednak wydaje się ciagłość typów motywacyjnych — oprócz nowych źródeł motywacji pojawiają się również dawne — maść zwierzęcia, jego wygląd zewnętrzny. Repertuar imion jest obszerny, przede wszystkim są to nazwy obcego pochodzenia, chociaż w zebranym materiale odnotowano imiona pojawiające się już pod koniec XV w. i zaświadczone np. w Nomenklaturze ogarów Jana Ostroroga. 


\section{WYKAZ SKRÓTÓW}

$$
\begin{aligned}
& \text { pol. } \quad \text { - język polski } \\
& \text { cz. } \quad \text { - język czeski } \\
& \text { słwc. }- \text { język słowacki } \\
& \text { ch. } \quad \text { - język chorwacki } \\
& \text { sr. } \quad \text { - język serbski } \\
& \text { słwń. - język słoweński } \\
& \text { ch } \quad \text { - chomik } \\
& \mathrm{f} \quad \text { - fretka } \\
& \text { jk } \quad \text { - jaszczurka } \\
& \mathrm{k} \quad \text { - kot } \\
& \mathrm{ka} \quad \text { - kotka } \\
& \mathrm{kn} \quad \text { - kanarek } \\
& \mathrm{kr} \quad \text { - królik }
\end{aligned}
$$

$$
\begin{aligned}
& \mathrm{m} \text { - mysz } \\
& \text { mk - myszoskoczek } \\
& \text { p - pies } \\
& \text { pg - papuga } \\
& \text { pj - pająk } \\
& \mathrm{r} \text { - rybka } \\
& \text { s - suka } \\
& \text { sz - szczur } \\
& \text { szn — szynszyla } \\
& \text { św _ świnka morska } \\
& \text { w - wąz } \\
& \text { Ż — żółw }
\end{aligned}
$$

\section{LITERATURA}

Abramowicz Z. 1996: Nazwy zwierzat gospodarskich we wsiach pólnocno-wschodniej Polski, [w:] M. Majtán, F. Ruščák (red.), 12. slovenská onomastická konferencia a 6. seminár „Onomastika a škola”. Prešov 25.-26. októbra 1995. Zbornik referátov, Pedagogická fakulta UPJŠ, Prešov, s. $282-286$.

Brozović Rončević D., Čilaš Šimpraga A. 2008: Nacrt za zoonomastička istraživanja (na primjeru imena konja), „Folia onomastica Croatica” XVII, s. 37-58.

Bubak J. 1996: Nazwy psów rasowych (na podstawie materiatu z krakowskiej kartoteki Polskiego Zwiqzku Kynologicznego), [w:] S. Warchoł (red.), Systemy zoonimiczne w językach słowiańskich. księga referatów V Międzynarodowej Slawistycznej Konferencji Naukowej, Lublin, 24-27 listopada 1993 rok, „Rozprawy Slawistyczne” XI, Wyd. UMCS, Lublin, s. 185-198.

Decyk W. 1996: Ksztaltowanie się nazw zwierzat domowych $w$ gospodarstwach wiejskich, [w:] M. Majtán, F. Ruščák (red.), 12. slovenská onomastická konferencia a 6. seminár „Onomastika a škola”. Prešov 25.-26. októbra 1995. Zborník referátov, Pedagogická fakulta UPJŠ, Prešov, s. 271-277.

Górnowicz H. 1959: Zawołania zwierzat domowych w Sztumskiem. Osiagnięcia i postulaty w dziedzinie badań zoonomastycznych w Polsce, „Onomastica” V, s. 451-462.

Jakus-Borkowa E. 1996.: Nazwy własne zwierzą ogrodów zoologicznych w Opolu i we Wrocławiu, [w:] S. Warchoł(red.), Systemyzoonimiczne wjęzykach stowiańskich. Księga referatów VMiędzynarodowej Slawistycznej Konferencji Naukowej, Lublin, 24-27 listopada 1993 rok, „Rozprawy Slawistyczne” XI, Wyd. UMCS, Lublin, s. 199-215.

Lindert B. 1970: Przyrostki stużace do tworzenia nazw zwierzat domowych na terenie Serbii i Chorwacji, „Studia z Filologii Polskiej i Słowiańskiej” IX, s. 235-242.

Lindert B. 1980: Formanty używane do tworzenia nazw zwierzat i ptactwa domowego w językach zachodniostowiańskich, „Slavia Occidentalis” XXXVII, s. 51-64.

Matejčík J. 1996: Nominácia v kynológii, [w:] M. Majtán, F. Ruščák (red.), 12. slovenská onomastická konferencia a 6. seminár „, Onomastika a škola”. Prešov 25.-26. októbra 1995. Zborník referátov, Pedagogická fakulta UPJŠ, Prešov, s. 320-324.

Mrózek R. 1994: Wtaściwości systemowe zoonimii, [w:] E. Krošláková (red.), Jazyková a mimojazyková stránka vlastných mien. 11. slovenská onomastická konferencia. Nitra 19.-20. mája 1994. Zborník 
referátov, Jazykovedný ústav L’udovíta Štúra SAV-Vysoká škola pedagogická, Bratislava-Nitra, s. $183-188$.

Mrózek R. 1996: Miejsce zoonimii w proprialnej sferze języka (o pojęciu systemu zoonimicznego), [w:] S. Warchoł (red.), Systemy zoonimiczne w językach słowiańskich. Księga referatów V Międzynarodowej Slawistycznej Konferencji Naukowej, Lublin, 24-27 listopada 1993 rok, „Rozprawy Slawistyczne” XI, Wyd. UMCS, Lublin, s. 75-83.

Nowakowska M. M. 2001: O Amikach, Czikach i innych imionach psów nie tylko rasowych, [w:] T. Michalewski (red.), Wspótczesna leksyka, cz. 2, Wyd. UŁ, s. 41-51.

Odaloš P. 1996: Zoonymá na strednom Slovensku. Mená kráv, býkov/volov, koni a kobýl, [w:] M. Majtán, F. Ruščák (red.), 12. slovenská onomastická konferencia a 6. seminár „, Onomastika a škola”. Prešov 25.-26. októbra 1995. Zborník referátov, Pedagogická fakulta UPJŠ, Prešov, s. 297-303.

Strutyński J. 1996a: Urbozoonimia polska, Wyd. Tomasz Strutyński, Kraków.

Strutyński J. 1996b: Zoonimia miejska. Próba klasyfikacji, [w:] S. Warchoł (red.), Systemy zoonimiczne w językach słowiańskich. Księga referatów V Międzynarodowej Slawistycznej Konferencji Naukowej, Lublin, 24-27 listopada 1993 rok, „Rozprawy Slawistyczne” XI, Wyd. UMCS, Lublin, s. $217-228$.

Strutyński J. 1999: Metoda inspiracyjno-semantyczna w badaniach onomastycznych, [w:] M. Brzezina, H. Kurek (red.), Collectanea linguistica in honorem Casimiri Polański, Księgarnia Akademicka, Kraków, s. 255-267.

Strutyński J., Warchoł S. 2004: Nazewnictwo zoonimiczne w środowiskach wiejskich i miejskich, [w:] R. Mrózek (red.), Nazwy własne w języku, kulturze i komunikacji społecznej, Wyd. UŚ, Katowice, s. $99-129$.

Walczak B. 2004: Dzieje języka a nazwy własne, [w:] R. Mrózek (red.), Nazwy własne w języku, kulturze i komunikacji spolecznej, Wyd. UŚ, Katowice, s. 29-45.

Warchoł S. 2003: Genetyczne i strukturalno-semantyczne zwiqzki między antroponimiq ślaska i zoonimiq ludowa, [w:] R. Łobodzińska (red.), Przeszłość, teraźniejszość i przyszłość polskiej onomastyki, Wyd. Wrocławskiego Tow. Naukowego, Wrocław, s. 69-76.

\section{URBAN ZOONYMES IN SELECTED WESTERN AND SOUTHERN SLAVIC LANGUAGES}

\section{SUMMARY}

The aim of the research was to present the process of naming domestic animals (pets) in Slavic languages, to point out the factors that determine this process, and to show the similarities or differences occurring in urban zoonymy. Urban zoonymic units in 6 Slavic languages were analyzed: Polish, Czech and Slovak (the West Slavic branch) as well as Croatian, Serbian and Slovenian (the South Slavic branch).

Special attention was given to the most productive motivational sources for Slavic animal nomenclature and different ways of derivation. The material for the paper was collected by means of a questionnaire and field research. The synchronic research method was chosen as the most suitable for the subject, with consideration of the sociolinguistic aspect and the semantic-inspirational method proposed by J. Strutyński.

Comparative analysis of the material was performed from three different perspectives: semantic, formal, and sociolinguistic.

Key w ords: urban zoonym, onomastics, Slavic languages 